ks. Jan Dyduch

Uniwersytet Papieski Jana Pawła II w Krakowie

\title{
Zadania
}

\section{Uniwersytetu Papieskiego Jana Pawła II w Krakowie w świetle jego aktualnego Statutu}

Uniwersytet Papieski Jana Pawła II w Krakowie (UP JPII), erygowany 19 czerwca 2009 roku, jest uczelnią kościelną i papieską. Kościelną - to znaczy, że jest w Kościele i dla Kościoła, i to rzutuje na jego zadania. Jest także papieski, co wskazuje na jego rangę i łączność z Głową Kościoła - papieżem. Nadrzędnym zadaniem uniwersytetu, z wyżej wymienionych powodów, jest służba Kościołowi. Służąc Kościołowi, uniwersytet służy także Ojczyźnie Polsce. Ta szczególna służba Kościołowi i Ojczyźnie wyraża się w budowaniu wspólnoty akademickiej i jej jedności, co w dalszej perspektywie sprzyja budowaniu wspólnoty kościelnej i narodowej. Przez realizowanie programu studiów Uniwersytet troszczy się o rozwój nauki i wychowanie młodego pokolenia.

\section{Budowanie wspólnoty akademickiej}

Podczas pierwszej inauguracji roku akademickiego na Uniwersytecie Papieskim w Krakowie 2009/2010 jego rektor powiedział: „Nasz Uniwersytet Papieski można porównać do płynącej łodzi. Łódź płynie wówczas bezpiecznie, jeśli wszyscy na niej obecni współdziałają we wspólnym rejsie. Jeśli darzą się życzliwością, wzajemnie sobie pomagają i są solidarni. Na łodzi, której na imię Uniwersytet Papieski, płynie cała wspólnota akademicka, pracownicy i studenci, a poniekąd także absolwenci i emeryci. Wszyscy jesteśmy za tę naszą łódź 
odpowiedzialni”' Powyższe porównanie uniwersytetu do łodzi ma uzmysłowić, że wszyscy uczestnicy tej wspólnoty akademickiej są ze sobą bardzo mocno powiązani, są wzajemnie za siebie odpowiedzialni i odpowiedzialni za całą uczelnię. Ta troska o całość uczelni, jej istnienie, działalność i rozwój jest nie tylko „pobożnym życzeniem”, ale realnym zadaniem całej wspólnoty.

Wspólnota uniwersytetu jest poniekąd odzwierciedleniem wspólnoty Kościoła. Sobór Watykański II naucza: „Chrystus, jedyny Pośrednik, ustanowił swój święty Kościół, tę wspólnotę wiary, nadziei i miłości tu na ziemi, jako widzialny organizm; nieustannie go też podtrzymuje; przez niego prawdę i ła-

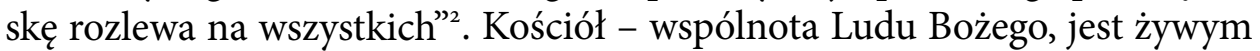
organizmem, podobnie jak uniwersytet - wspólnota akademicka. Kościół jest Mistycznym Ciałem Chrystusa, zaś Uniwersytet Papieski służy Chrystusowi i Kościołowi. Chodzi zresztą nie o identyczność Kościoła ze wspólnotą akademicką uniwersytetu, lecz o pewną analogię obydwu wspólnot. Ponadto Kościół stanowi wspólnotę wspólnot, Uniwersytet Papieski przez swój charakter i zadania jest znaczącą wspólnotą w tej rzeczywistości.

Odpowiedzialnością za Uniwersytet Papieski obarcza wspólnotę akademicką jego Statut: „Cała wspólnota akademicka, władze kolegialne i indywidualne, pracownicy naukowo-dydaktyczni i dydaktyczni, pracownicy niebędący nauczycielami akademickimi, doktoranci i studenci, wszyscy w ramach swych funkcji są odpowiedzialni za dobro Uniwersytetu i winni dbać o jego rozwój”’3. Tak więc wspólnotę akademicką uniwersytetu stanowią jego władze, nauczyciele akademiccy, pracownicy administracji i obsługi, doktoranci i studenci. Statut zasadniczo nie przewiduje zatrudnienia pracowników naukowych nieprowadzących zajęć dydaktycznych. Odpowiedzialność i troska poszczególnych grup wspólnoty zróżnicowana jest w zależności od podejmowanych zadań.

Szczególne zadania we wspólnocie uniwersyteckiej spełniają jej władze: „W stosunku do całego Uniwersytetu władzę - zgodnie ze swoimi kompetencjami - posiadają: wielki kanclerz, rektor i senat, a w stosunku do poszczególnych wydziałów dziekan, rada wydziału, natomiast w instytutach: dyrektor i rada instytutu, zgodnie ze swymi regulaminami. W stosunku do Wydziału

J. Dyduch, Przemówienie inauguracyjne, 16.10.2009, [w:] Pierwsza uroczysta inauguracja roku akademickiego UPJPII 2009/2010, red. R. Bogacz, Kraków 2009, broszura, s. 9.

2 Konstytucja soborowa Lumen gentium (KK), n. 8.

3 Statut Uniwersytetu Papieskiego Jana Pawła II w Krakowie (Statut UPJPII), 8.06.2015, broszura, par. 14 . 
Teologicznego Sekcja w Tarnowie władzę posiada także wielki wicekanclerz" ${ }^{\text {". }}$ Władzę w stosunku do uniwersytetu sprawuje także Kongregacja Edukacji Katolickiej, która działa w imieniu i z upoważnienia papieża. Władza uniwersytetu jest wykonywana zarówno przez osoby fizyczne, np. rektora, jak i przez kolegia, np. senat. Rola i zadania wymienionych władz uczelni wymagają odrębnego omówienia.

W uniwersyteckiej wspólnocie wiodącą rolę odgrywają nauczyciele akademiccy. To oni przede wszystkim mają nauczać i wychowywać młodzież akademicką, słowem i świadectwem życia uczyć ją miłości do Kościoła i Ojczyzny. Oni też mają pielęgnować tradycyjne wartości akademickie i ożywiać relacje uniwersyteckie, streszczające się w zasadzie "mistrz-uczeń". To wymaganie stawia konstytucja Sapientia christiana: „Każdy wydział powinien mieć liczbę wykładowców, przede wszystkim stałych, odpowiednią do rangi i rozwoju poszczególnych dyscyplin, jak również zapewniającą konieczną troskę o studentów i ich postęp"s. Wykładowcy winni posiadać odpowiednią wiedzę fachową, prezentować należyty poziom etyczny i doświadczenie pedagogiczne. Wiedza wykładowców ma być potwierdzona stopniami lub tytułami naukowy$\mathrm{mi}$, odpowiadającymi wymogom stawianym na innych wyższych uczelniach danego kraju oraz uznawanym tam dorobkiem naukowym ${ }^{6}$.

Przywołane wymagania stawia nauczycielom akademickim Statut: „Nauczycielem akademickim może zostać osoba, która posiada kwalifikacje określone prawem państwowym i kanonicznym, wykazuje predyspozycje do pracy z młodzieżą i uzdolnienia do pracy naukowej, wiernie przyjmuje doktrynę katolicką, kieruje się w życiu zasadami etyki katolickiej, dobrze wypełnia swoje obowiązki i troszczy się o dobro Uniwersytetu"7. Szczególniejsze wymagania stawia się nauczycielom akademickim wykładającym dyscypliny kościelne. Mają oni otrzymać od wielkiego kanclerza uniwersytetu misję kanoniczną, a swoje zadania wykonywać w zgodzie z Urzędem Nauczycielskim Kościoła.

Uniwersytet zatrudnia nauczycieli akademickich, którymi są pracownicy naukowo-dydaktyczni i pracownicy naukowi, posiadający stanowiska: profesora

\footnotetext{
4 Tamże, par. 16.

5 Jan Paweł II, Konstytucja Sapientia christiana (sch), 15.04.1979, A AS 71 (1979), s. 469-499, tłumaczenie w: Posoborowe prawodawstwo kościelne, t. 12, z. 1, zebrał i przeł. ks. E. Sztafrowski, Warszawa 1983, s. 210-256, art. 22.

6 Por. tamże, art. 23-25.

7 Statut UPJPII, par. 58 u. 2.

8 Por. tamże, par. 58 u. 3, par. 17 u. 1 i.
} 
zwyczajnego, profesora nadzwyczajnego, profesora wizytującego, adiunkta i asystenta. Do nauczycieli akademickich należą także pracownicy dydaktyczni zatrudnieni na stanowiskach: starszego wykładowcy, wykładowcy, lektora i instruktora. Nauczycielami akademickimi są również dyplomowani bibliotekarze oraz dyplomowani pracownicy dokumentacji i informacji naukowej ${ }^{9}$. Pracownikami zatrudnionymi na uniwersytecie, niebędącymi nauczycielami akademickimi, są: pracownicy biblioteki oraz dokumentacji i informacji naukowej, a także pozostali pracownicy uczelni, wśród nich pracujący w administracji $1^{\circ}$.

We wspólnocie akademickiej Uniwersytetu Papieskiego uczestniczą również studenci i doktoranci, którzy winni się w jej życie zaangażować. Wśród ich zadań jawi się przede wszystkim zdobywanie wiedzy i kształtowanie charakteru: "Studenci zaś nie mogą być nastawieni tylko na branie, ale mają dawać swój codzienny wysiłek i trud, aby nie tylko zdobyć wykształcenie, ale ukształtować w sobie szlachetny charakter, rozwijać w sobie talenty i zdolności, być solidarni między sobą, a także ze wszystkimi pracownikami, szanować swoich nauczycieli i pracowników obsługi”"11. Program zadań studenta i doktoranta zawarty jest w ślubowaniu składanym podczas immatrykulacji. Wówczas przyjęci na studia zobowiązują się pracować nad zdobywaniem wykształcenia, nad kształtowaniem swojej osobowości, postępować zgodnie z prawem, tradycjami i dobrymi obyczajami akademickimi oraz zachowywać postawę godną członka wspólnoty Kościoła i świadomego obywatela Ojczyzny ${ }^{12}$.

Studentem Papieskiego Uniwersytetu może zostać osoba posiadająca uznawane przez państwo świadectwo dojrzałości. Ma ona respektować kościelny charakter uniwersytetu, kierować się zasadami moralności chrześcijańskiej, jak również spełniać inne wymagania zawarte w przepisach obowiązujących na uniwersytecie ${ }^{13}$. Studenci mają prawo do rozwoju naukowego przez korzystanie $\mathrm{z}$ wykładów, ćwiczeń, seminariów naukowych, praktyk i innych zajęć przewidzianych w programie studiów. Mogą starać się o tytuły zawodowe i stopnie naukowe, przysługuje im prawo ubiegania się o pomoc materialną, a także uczestniczenia przez swoich przedstawicieli w kolegialnych organach władz uczelni ${ }^{14}$.

9 Por. tamże, par. 55 .

10 Por. tamże, par. 56, 95.

" J. Dyduch, Przemówienie inauguracyjne, dz. cyt., s. 7-8.

12 Por. Statut UPJPII, par. 76, p. 7-8.

13 Por. tamże, par. 76, p. 1-4.

${ }_{14}$ Por. tamże, par. 76, p. 10. 
Omawiając udział studentów we wspólnocie Uniwersytetu Papieskiego, nie można uciec od pytania: czy do tej wspólnoty mogą należeć i w niej uczestniczyć studenci innych wyznań niż katolickie, innych religii i niewyznający żadnej religii? Przestrzegając zasady o ekumenizmie, o wolności religijnej i wolności sumienia, nikogo nie można wyłączyć. Zresztą Statut, określając tekst ślubowania studentów, stwierdza, iż wyżej wymieni mogą opuścić niektóre sformułowania $\mathrm{z}$ roty ślubowania ${ }^{15}$. Poza tym studentom UPJPII przysługują wszystkie prawa studentów wymienione w polskim prawie państwowym, zgodnie z Umową między Rządem Rzeczypospolitej Polskiej a Konferencją Episkopatu Polski ${ }^{16}$. Jak wspomnieliśmy wyżej, wszyscy studenci Uniwersytetu Papieskiego mają obowiązek respektować jego kościelny charakter.

\section{Troska o rozwój nauki}

We wspólnocie akademickiej Uniwersytetu Papieskiego jako główne zadanie jawi się wychowanie i rozwój nauki, o czym już wspominaliśmy. Proces wychowawczy, w którym uczestnicą zarówno pracownicy, jak i studenci, jest nierozłącznie związany z działalnością Uniwersytetu Papieskiego. Jako uniwersytet kościelny czerpie on swoje zasady wychowawcze z Ewangelii i nauczania Kościoła, które inspirują zarówno wychowawców, jak i wychowanków. Ewangelizacja i nowa ewangelizacja są zadaniem poniekąd naturalnie związanym z Uniwersytetem Papieskim. Jest on także prawdziwym uniwersytetem, dlatego ma troszczyć się o wysoki poziom naukowy, o dobro i rozwój nauki. W procesie naukowym i naukowo-dydaktycznym uniwersytet stawia wymagania, które w dziedzinie poziomu naukowego mają dorównywać standardom innych uczelni w Polsce, a nawet je przewyższać. Te wymagania dotyczą w pierwszej kolejności nauczycieli akademickich. Statut postanawia: „Troska o stan badań naukowych i poziom nauczania spoczywa na nauczycielach akademickich, którzy są zobowiązani traktować swoje zajęcia jako pierwszoplanowe" ${ }^{117}$. Zobowiązuje on także studentów i doktorantów do godnego reprezentowania uniwersytetu, do pilnego uczestnictwa w zajęciach dydaktycznych i organizacyjnych, do składania egzaminów, zdobywania zaliczeń i odbywania praktyk ${ }^{18}$.

\footnotetext{
15 Por. tamże, par. 76, p. 7-8.

16 Por. Dz.U. z 30.07.1999, Nr 63 poz. 727, par. 5.

17 Statut UPJPII, par. 14 .

18 Por. tamże, par. 76, p. 11.
} 
Nauczyciele akademiccy są zobowiązani zadbać o awanse naukowe, o własny rozwój naukowy, a także o dobro nauki na uczelni. Konstytucja Sapientia christiana poleca, aby każdy wydział miał odpowiednią liczbę wykładowców, zapewniających troskę o nauczanie studentów i ich rozwój naukowy. Winni oni poprzez opublikowane rozprawy naukowe wykazać zdolność do podejmowania badań naukowych oraz posiadać wystarczającą wiedzę w swojej specjalności. Wiedza ta winna być potwierdzona odpowiednim tytułem czy stopniem naukowym oraz umiejętnościami pedagogicznymi i poczuciem odpowiedzialności. Przywołane wymagania i walory winny być stawiane i postrzegane odpowiednio do wymogów i praktyki stosowanej na innych uczelniach danego kraju. Te sprawy mają być precyzyjnie określone przez statuty uniwersytetu czy wydziału, które także winny wymienić władze kompetentne i odpowiedzialne za dobór oraz za awanse wykładowców ${ }^{19}$.

Powyższe zagadnienie podejmuje Statut uniwersytetu. Postanawia on, że tytuł naukowy profesora nadaje wielki kanclerz po przeprowadzeniu odpowiedniego postępowania przez Radę Wydziału i uzyskaniu pozytywnej decyzji Centralnej Komisji do Spraw Stopni i Tytułów. Stanowisko profesora zwyczajnego nadaje wielki kanclerz osobie spełniającej wymogi zawarte w regulaminie uczelni i która uzyskała nihil obstat Stolicy Apostolskiej. Stanowisko profesora nadzwyczajnego nadaje rektor osobie spełniającej wymogi określone w regulaminie, po uzyskaniu nihil obstat Stolicy Apostolskiej. Stopień naukowy doktora habilitowanego nadaje Rada Wydziału, po przeprowadzeniu postępowania habilitacyjnego, zgodnie z przepisami prawa państwowego i regulaminu uczelni. Dyplom doktora habilitowanego wręcza wielki kanclerz. Na pozostałe stanowiska nauczycieli akademickich na uniwersytecie zatrudnia rektor zgodnie z przepisami zawartymi w Statucie i regulaminach uczelni ${ }^{20}$.

Studenci i doktoranci mają troszczyć się o zdobywanie wiedzy i potwierdzanie jej tytułami zawodowymi i stopniami naukowymi. Zgodnie z konstytucją Sapientia christiana na Uniwersytecie Papieskim nadaje się następujące stopnie akademickie: bakalaureat, licencjat i doktorat. W statutach poszczególnych uniwersytetów i wydziałów wymienione stopnie mogą także otrzymać inne nazwy, biorąc pod uwagę praktykę uniwersytetów danego regionu. Należy jednak jasno sprecyzować ich równoważność z wymienionymi wyżej stopniami akademickimi, jak również zachować jednolitość na uniwersytetach

19 Por. sch, art. 22-26.

${ }^{20}$ Por. Statut UPJPII, par. 60-65. 
i wydziałach kościelnych tego samego regionu ${ }^{21}$. Przywołane wyżej określenie "tytuły zawodowe" nie występuje w konstytucji Sapientia christiana, ale do Statutu UPJPII zostało wprowadzone dlatego, że pojawia się w polskim prawie dotyczącym szkolnictwa wyższego. Także nazewnictwo stopni akademickich w tymże prawie różni się od kościelnego prawodawstwa kościelnego. Statut UPJPII posługuje się zasadniczo nazewnictwem stopni akademickich zaczerpniętym z prawodawstwa polskiego i zgodnie z wymogiem przywołanej konstytucji podaje ich równoważność z prawem kościelnym.

Na Uniwersytecie Papieskim nadaje się tytuł licencjata zawodowego. Ten tytuł otrzymać można na Wydziale Filozoficznym, na Wydziale Historii i Dziedzictwa Kulturowego oraz na Wydziale Nauk Społecznych. Na tych wydziałach jest on równoważny stopniowi bakalaureatu ${ }^{22}$. Na Wydziale Teologicznym, Wydziale Teologicznym Sekcja w Tarnowie i Wydziale Prawa Kanonicznego nie nadaje się tytułu licencjata zawodowego. Do otrzymania tytułu licencjata zawodowego wymaga się od kandydata: zaliczenia zajęć przewidzianych w programie studiów, przedłożenia pozytywnie ocenionej pracy dyplomowej, zdania egzaminu końcowego i spełnienia wymagań określonych przez regulamin i postanowienia Rady Wydziału ${ }^{23}$. Trzeba dodać, iż określenie "tytuł licencjata zawodowego" pojawił się w polskim prawodawstwie państwowym o szkolnictwie wyższym w roku 199o. Różni się on znacznie od stopnia akademickiego licencjata, który od dawna jest w prawie kanonicznym. Dla odróżnienia od licencjata zawodowego jest nazwany licencjatem kościelnym lub naukowym. Po wprowadzeniu tytułu licencjata zawodowego w polskich uczelniach kościelnych, ze względu na zapewnienie odpowiedniości stopni akademickich w szkolnictwie państwowym i kościelnym, trzeba było dokładnie opisać w Statucie UPJPII jeden i drugi, ukazując różnicęe $e^{24}$.

Tytuł zawodowy magistra nadaje się na wszystkich wydziałach Uniwersytetu Papieskiego. Na Wydziale Teologicznym i na Wydziale Teologicznym Sekcja $\mathrm{w}$ Tarnowie jest on równoważny stopniowi bakalaureatu; zaś na Wydziale Filozoficznym, Wydziale Historii i Dziedzictwa Kulturowego oraz Wydziale Nauk Społecznych tytuł zawodowy magistra jest równoważny stopniowi

${ }^{21}$ Por. sch, art. 47-48.

${ }^{22}$ Por. Statut UPJPII, par. 78.

${ }^{23}$ Por. tamże, par. 79.

${ }_{24}$ Por. J. Dyduch, Organizacja $i$ awanse naukowe $w$ Uniwersytecie Papieskim Jana Pawła II w Krakowie, „Analecta Cracoviensia” 46 (2013), s. 290. 
licencjata naukowego (kościelnego ${ }^{25}$. Do uzyskania tytułu zawodowego magistra na przywołanych wydziałach należy: zaliczenie zajęć przewidzianych programem studiów, przedłożenie pracy magisterskiej, która została pozytywnie oceniona przez recenzenta - samodzielnego pracownika naukowego, zdanie egzaminu i obrona pracy, wypełnienie pozostałych przepisów kościelnych i państwowych ${ }^{26}$.

Nieco inaczej kształtuje się nadanie tytułu zawodowego magistra na Wydziale Prawa Kanonicznego, którego działalność jest regulowana odrębnym statutem zatwierdzonym przez Stolicę Apostolskąa ${ }^{27}$. Postanawia on, że wydział nadaje tytuł zawodowy magistra prawa kanonicznego, który jest równoważny kościelnemu, naukowemu stopniowi licencjata prawa kanonicznego ${ }^{28}$. Warto dodać, że przywołany stopień, stosownie do przepisów kanonicznego prawodawstwa powszechnego, daje uprawnienia do pracy w sądach i innych urzędach kościelnych (por. kan. $1420 \$ 4$, kan. $1421 \S 3$, kan. 1435 Kodeksu prawa kanonicznego). Celem uzyskania stopnia licencjata naukowego (kościelnego) należy: uczestniczyć w zajęciach przewidzianych programem studiów i zdać wymagane egzaminy, przedłożyć pracę licencjacką ocenioną pisemnie przez promotora i recenzenta - samodzielnych pracowników naukowych, zdać egzamin z prawa kanonicznego połączony z obroną pracy. Praca magisterska może zostać uznana za licencjacką, gdy spełni wymogi określone w odpowiednim regulaminie ${ }^{29}$.

Na wszystkich wydziałach UPJPII może zostać nadany stopień naukowy doktora. Nadaje go Rada Wydziału, posiadająca odpowiednie quorum pracowników naukowych, po przeprowadzeniu procedury zgodnej z obowiązującymi przepisami państwowymi i regulaminami uniwersytetu ${ }^{30}$. Wydziały Uniwersytetu Papieskiego posiadające wymagane uprawnienia mogą nadawać stopień naukowy doktora habilitowanego. Stopień ten nadaje Rada Wydziału na podstawie przeprowadzonego postępowania habilitacyjnego, które zostało dokonane zgodnie z obowiązującymi przepisami państwowymi i regulaminem uniwersytetu ${ }^{31}$. Doktorat honoris causa może zostać nadany przez Radę

\footnotetext{
25 Por. Statut UPJPII, par. 78.

26 Por. tamże, par. 79.

${ }_{27}$ Kongregacja Edukacji Katolickiej, Dekret, n. 175/2011, 19.03.2014, Archiwum UPJPII.

28 Por. Statut Wydziału Prawa Kanoniczego UPJPII w Krakowie, maszynopis, art. 27.

29 Por. Statut UPJPII, par. 80.

30 Por. tamże, par. 81.

${ }^{31}$ Por. tamże, par. 82, 64 .
} 
Wydziału osobom szczególnie zasłużonym dla Kościoła, po uzyskaniu zgody senatu i wielkiego kanclerza, a także po otrzymaniu nihil obstat Stolicy Apostolskiej i przeprowadzeniu procedury stosownie do regulaminu uniwersytetu $\mathrm{u}^{32}$.

Wszystkie wydziały uniwersytetu posiadające wymagane quorum pracowników naukowych mogą przeprowadzać postępowanie do nadania tytułu naukowego profesora. Po przeprowadzeniu postępowania zgodnie z przepisami państwowymi i kościelnymi oraz umową między państwem a Kościołem, wielki kanclerz nadaje tytuł profesora, po otrzymaniu pozytywnej decyzji Centralnej Komisji do Spraw Stopni i Tytułów ${ }^{33}$.

Warunkiem uzyskania awansów naukowych na uniwersytecie papieskim jest systematyczne realizowanie programu studiów.

\section{Realizacja programu studiów}

Uniwersytet Papieski realizuje swój program na następujących wydziałach: Wydziale Teologicznym, Wydziale Teologicznym Sekcja w Tarnowie, Wydziale Filozoficznym, Wydziale Prawa Kanonicznego, Wydziale Historii i Dziedzictwa Kulturowego oraz Wydziale Nauk Społecznych ${ }^{34}$. Erygowanie nowych wydziałów jest zarezerwowane dla Kongregacji Edukacji Katolickiej. Wydziały te są podstawowymi jednostkami organizacyjnymi uniwersytetu i stanowią autonomiczne środowiska naukowe. Ich zadaniem jest prowadzenie działalności naukowo-badawczej, dydaktycznej, kształcenie kadry naukowej w dziedzinie własnych kompetencji oraz przeprowadzanie przewodów i postępowań, które zmierzają do nadawania stopni akademickich, tytułów zawodowych i tytułu naukowego ${ }^{35}$.

Wydziały składają się z instytutów, katedr, zakładów i innych jednostek prowadzących działalność dydaktyczno-badawczą. Tworzy je, łączy, przekształca i likwiduje Rada Wydziału, uwzględniając uchwały senatu na ten temat. Katedra ma prowadzić działalność naukowo-badawczą i dydaktyczną określoną przez właściwy sobie obszar badawczy i przedmiot nauczania. Celem intensyfikacji pracy naukowo-badawczej i dydaktycznej poszczególne katedry mogą być połączone w instytuty wydziałowe, międzywydziałowe lub międzyuczelniane. Instytuty wydziałowe organizuje Rada Wydziału. Instytuty międzywydziałowe

\footnotetext{
32 Por. tamże, par. 83 .

33 Por. tamże, par. 60, 84 .

34 Por. tamże, par. 8.

35 Por. tamże, par. 10.
} 
i międzyuczelniane organizuje senat, czyli tworzy je, kształtuje i likwiduje. Senat także nadaje im regulaminy i podejmuje uchwały $\mathrm{w}$ sprawie ich działalności oraz powołuje i odwołuje dyrektorów instytutów ${ }^{36}$.

Poszczególne wydziały mogą w miarę aktualnych potrzeb organizować studia wydziałowe, międzywydziałowe i międzyuczelniane. Ich zadaniem jest pogłębianie wiedzy w dziedzinie specjalności reprezentowanych przez dany wydział dotyczący własnych lub innych absolwentów ${ }^{37}$. Przywołana norma odzwierciedla poniekąd rozbudowany w przeszłości system studiów przywydziałowych w Krakowskiej Uczelni Teologicznej. Były one wielokierunkowe i miały różny profil: liturgiczny, katechetyczny, ascetyczny, duszpasterstwo rodzin oraz studium myśli współczesnej. Wszystkie one służyły dokształcaniu kapłanów i świeckich zaangażowanych w apostolstwo. Miały także za zadanie wyjaśniać dokumenty kościelne dokonujące posoborowej odnowy Kościoła ${ }^{38}$.

Program studiów Uniwersytetu Papieskiego pomagają realizować następujące jednostki międzywydziałowe: Międzywydziałowy Instytut Bioetyki, Międzywydziałowy Instytut Ekumenii i Dialogu, Międzywydziałowe Studium Języków Obcych, Międzywydziałowe Studium Wychowania Fizycznego i Ośrodek Badań nad Myślą Jana Pawła II. Czynią to także jednostki międzyuczelniane: Centrum Kopernika Badań Interdyscyplinarnych i Międzyuczelniany Instytut Muzyki Kościelnej. Pomagają również takie instytucje jak: Fundacja im. Świętej Jadwigi Królowej dla UPJPII, Księgarnia Logos i Wydawnictwo Naukowe UPJPII ${ }^{39}$. Szczególną rolę w tym dziele odgrywa Biblioteka Główna, która stanowi jednolity system biblioteczno-informacyjny. Biblioteka gromadzi, opracowuje, przechowuje i udostępnia zbiory biblioteczne związane z działalnością naukowo-dydaktyczną oraz na ich podstawie prowadzi działalność informacyjną. Kieruje nią dyrektor powoływany i odwoływany przez rektora, po zasięgnięciu opinii senatu. W sprawach biblioteki rektor zasięga opinii Senackiej Komisji Bibliotecznej ${ }^{40}$.

Konstytucja Sapientia christiana następująco ukierunkowuje program studiów: „W programie studiów należy dokładnie przestrzegać zasad i norm, które odnośnie do różnych przedmiotów są zawarte w dokumentach kościelnych, zwłaszcza Soboru Watykańskiego II. Równocześnie trzeba mieć na uwadze

\footnotetext{
${ }_{36}$ Por. tamże, par. 11-12; par. 27, p. 3, 7, 13 b.

37 Por. tamże, par. 13.

38 Por. J. Dyduch, Organizacja i awanse naukowe..., dz. cyt., s. 284.

39 Por. Pierwsza uroczysta inauguracja..., dz. cyt., s. 32-33.

40 Por. Statut UPJPII, par. 85-88.
} 
osiągnięcia wynikające z postępu naukowego, które w szczególny sposób przyczyniają się do rozwiązywania aktualnych problemów" ". Przywołane wytyczne konstytucji realizuje Statut UPJPII, polecając uwzględniać w realizowaniu kształcenia metody naukowo-badawcze właściwe każdej z dyscyplin. Należy studentom ukazywać związek życia z wiarą, uczyć ich szacunku dla prawdy, godności ludzkiej i kultury. Uczyć ich mądrości tak, aby nabrali nawyku uczenia się przez całe życie. Temu mają służyć: „Badania naukowe i nauczanie winny być ukierunkowane na pogłębianie znajomości prawdy zawartej w Objawieniu chrześcijańskim i na rozwiązywaniu w jego świetle problemów, przed którymi stoją Kościół i społeczeństwo"42.

Konstytucja Sapientia christiana wymaga, aby przebieg studiów na każdym wydziale był podzielony na trzy cykle. Podczas pierwszego cyklu należy przekazywać wiadomości ogólne, związane ze wszystkimi dyscyplinami, i nauczyć posługiwania się metodą naukową. W drugim cyklu trzeba przeprowadzić pogłębione studium określonego zestawu dyscyplin i udoskonalanie posługiwania się metodą naukową. Trzeci cykl ma prowadzić do dojrzałości naukowej i napisania rozprawy przyczyniającej się do postępu nauki ${ }^{43}$. Program studiów poszczególnych wydziałów Uniwersytetu Papieskiego w Krakowie odzwierciedla te trzy cykle. Na Wydziale Teologicznym i Wydziale Teologicznym Sekcja w Tarnowie pierwszy cykl prowadzi do magisterium, drugi do licencjata naukowego, a trzeci do doktoratu. Na Wydziale Filozoficznym, Wydziale Historii i Dziedzictwa Kulturowego oraz Wydziale Nauk Społecznych pierwszy cykl prowadzi do licencjata zawodowego, drugi do magisterium, trzeci do doktoratu. Na Wydziale Prawa Kanonicznego dwa pierwsze cykle prowadzą do magisterium i równoważnego mu licencjata naukowego, trzeci zaś do doktoratu ${ }^{44}$.

Działalność dydaktyczna uniwersytetu prowadzona jest poprzez wykłady, ćwiczenia, seminaria naukowe, praktyki i inne zajęcia objęte programem studiów. Studenci mają obowiązek uczestniczyć w nich zgodnie z programem regulaminu studiów ${ }^{45}$. Dla poszczególnych etapów studiów, a więc na koniec semestru, roku akademickiego czy jakiegoś cyklu, przewiduje się egzamin lub inny sprawdzian. Każdy cykl studiów kończy się zgodnie z regulaminem

\footnotetext{
${ }^{41}$ sch, art. 38, par. 1.

42 Statut UPJPII, par. 75, p. 4-5.

43 Por. sch, art. 40.

44 Por. Statut UPJPII, par. 75, p. 1-2.

45 Por. tamże, par. 75 , p. 6, par. 76 , p. 11 c.
} 
studiów egzaminem komisyjnym, dla uzyskania absolutorium lub określonego tytułu zawodowego lub stopnia naukowego ${ }^{46}$. Studia na Uniwersytecie Papieskim mają zasadniczo formę stacjonarną, ale są też prowadzone studia niestacjonarne. Organizowane są także studia podyplomowe oraz kursy dokształcające ${ }^{47}$.

\section{Zakończenie}

Aktualny Statut UPJPI I wyznacza uniwersytetowi jako jego istotne zadania: konstruktywną współpracę całej wspólnoty akademickiej, rozwój naukowy zarówno pracowników, jak i studentów oraz doktorantów, a także doskonalenie programu studiów i jego skuteczną realizację. W spełnianiu tych zadań pomocne mają być odpowiednie regulacje prawne. Oprócz Statutu uniwersytetu przewiduje się statuty poszczególnych wydziałów, zatwierdzone przez Stolicę Apostolską ${ }^{48}$. Taki statut wydziałowy posiada Wydział Prawa Kanonicznego. Wydaje się, że zamiast statutów wydziałowych można by sporządzić regulaminy poszczególnych wydziałów, przez nie przygotowane i zatwierdzone przez senat uniwersytetu, bez odnoszenia się do Stolicy Apostolskiej.

\section{ABstrakt}

\section{Zadania Uniwersytetu Papieskiego Jana Pawła II w Krakowie w świetle jego aktualnego Statutu}

Wiodącym zdaniem uniwersytetu jest służba Kościołowi i Ojczyźnie. Uniwersytet pozostaje w służbie Kościoła i przez ewangelizację oraz przez budowanie wspólnoty akademickiej, szczególnie pielęgnowania relacji „mistrz-uczeń”, wydatnie przyczynia się do umacniania jedności wspólnoty kościelnej. Uniwersytet, troszcząc się o udoskonalenie programu studiów i o rozwój nauki, kształcąc i wychowując młodzież w duchu patriotyzmu, służy Polsce.

\section{SŁOWA KLUCZOWE}

wspólnota akademicka, stopnie i tytuły naukowe, program studiów, Statut UPJPII

\footnotetext{
${ }_{46}$ Por. tamże, par. 76, p. 11d, par. 8 oc.

47 Por. tamże, par. 75, p. 1.

48 Por. tamże, par. 10.
} 


\section{Abstract \\ The aims of the Pontifical University of John Paul II in Krakow in the light of its current Statute}

The leading aim of the Pontifical University of John Paul II in Krakow is to be of service to the Church and Homeland, that is, Poland. The University is a part of the community of the Catholic Church. Consequently, evangelization and creating special bonds among the members of academic community is a method of achieving the aims of the University. The practice of fostering the model of a master-pupil relation is the most important element of the practice of the University. The authorities of the University take care of the agenda of studies, the development in the fields of research and science, and also of educating the young about patriotism.

\section{KEYWORDS}

community of University, academic and professional titles, Statute of the Pontifical University of John Paul II in Krakow

\section{BIBLIOGRAFIA}

\section{Źródła}

Jan Paweł II, Konstytucja apostolska Sapientia christiana, 15.04.1979, A AS 71 (1979), s. 469-499.

Statut Uniwersytetu Papieskiego Jana Pawła II w Krakowie, 8.06.2015, broszura. Statut Wydziału Prawa Kanonicznego UPJPII, 19.03.2014, maszynopis, Archiwum UPJPII.

\section{Literatura}

Dyduch J., Przemówienie inauguracyjne, 16.10.2009, [w:] Pierwsza uroczysta inauguracja roku akademickiego UPJPII 2009/2010, red. R. Bogacz, Kraków 2009, broszura, s. 3-8.

Dyduch J., Organizacja $i$ awanse naukowe w Uniwersytecie Papieskim Jana Pawła II w Krakowie, „Analecta Cracoviensia” 46 (2013), s. 281-295. 